\title{
The Minimum Requirements for Nickel and Cobalt as Trace Metals in Thermophilic Biogas Fermentation of Palm Oil Mill Effluents
}

\author{
IRVAN $^{\star 1,2}$, BAMBANG TRISAKTI ${ }^{1,2}$, FATIMAH BATUBARA ${ }^{1}$ and HIROYUKI DAIMON ${ }^{3}$ \\ ${ }^{1}$ Chemical Engineering Department, Universitas Sumatera Utara, Medan, 20155, Indonesia. \\ ${ }^{2}$ Sustainable Energy and Biomaterial Center of Excellence, Universitas Sumatera Utara, \\ Medan, 20155, Indonesia. \\ ${ }^{3}$ Department of Environmental and Life Sciences, Toyohashi University of Technology, \\ Toyohashi, 441-8580, Japan. \\ ${ }^{*}$ Corresponding author E-mail: irvan @ usu.ac.id \\ http://dx.doi.org/10.13005/ojc/340311
}

(Received: November 08, 2017; Accepted: March 06, 2018)

\begin{abstract}
This paper reports the minimum requirements of nickel and cobalt as trace metals in the formation of biogas from the digestion of palm oil mill effluent (POME). Anaerobic digestion was conducted in a two-liter continuous stirred tank reactor (CSTR) and operated at a thermophilic condition of $55{ }^{\circ} \mathrm{C}$. As raw material, a non-treated liquid waste from the mills was used. Hydraulic retention time (HRT) of the digesters was preserved at six days. The results come to the conclusion that the decrease of trace metals concentration didn't influence the total solid, volatile solid concentration and also M-alkalinity. Based on the analyzed parameter, the reduction of trace metals concentration up to $97 \%$ of the initial nickel and cobalt concentration, 0.49 and $0.42 \mathrm{mg} / \mathrm{L}$ for nickel and cobalt, still allows the fermentation to obtain optimum biogas production, where the $90 \%$ reduction of trace metals produced the average volume of biogas $10.5 \mathrm{~L} /$ day at the rate of VS degradation $52-53 \%$.
\end{abstract}

Keywords: Anaerobic digestion, Biogas, Palm oil mill effluent, Trace metal, Thermophilic

\section{INTRODUCTION}

Palm oil mill effluent (POME) is one of side products which come out from many sources in palm mills. Due to its high concentration of chemical oxygen demand (COD) around 50,000 $\mathrm{mg} / \mathrm{L}$ and biochemical oxygen demand (BOD) around 25,000 $\mathrm{mg} / \mathrm{L}$, it cannot be directly discharged into the rivers or lakes. The main components of this side product are cellulose and lignocellulosic. Based on these components which containing high organic and carbon content, the most appropriate method to treat this side product is by using anaerobic digestion ${ }^{1}$.

Anaerobic digestion is a series of processes that happens biologically when microorganism

This is an Open Access article licensed under a Creative Commons Attribution-Non Commercial-Share Alike 4.0 International License (https://creativecommons.org/licenses/by-nc-sa/4.0/), which permits unrestricted Non Commercial use, distribution and reproduction in any medium, provided the original work is properly cited. 
breaks down biodegradable material in environments with little or absence of oxygen. Anaerobically digesting organic carbon contains naturally occurring bacteria. The chemical reactions that occur in stages during anaerobic digestion are hydrolysis, acidogenesis, acetogenesis, and methanogenesis. These stages can be maintained and enhanced through engineering and chemistry².

Micronutrients and macronutrients have a significant effect on the growth of the microorganism and the biogas generation. The existence or absence of them can improve or limit the performance of the process. Macronutrients needed in the system are commonly considered to be phosphorus and nitrogen while micro-nutrients are the trace metals zinc, iron, nickel, and cobalt. Adding macro and micronutrients can give effect to the biogas yield ${ }^{3}$.

The previous method developed by Universitas Sumatera Utara (USU) and Metawater Co. Ltd. Japan concluded that the addition of trace metals nickel and cobalt was one of the driving forces for optimum biogas formation ${ }^{4}$. However, if this method is applied to the factories with the production capacity of 40 tons per hour, then the need for trace metal used for the processing of liquid waste will be high enough. If we assumed the production time of palm oil mill is $20 \mathrm{~h}$ per day, then the amount of POME to be processed in wastewater treatment about 600 tons per day. Therefore, based on the method developed by USU and Metawater Co. Ltd., converting POME to biogas required approximately $294 \mathrm{~g}$ of $\mathrm{NiCl}_{2}, 252 \mathrm{~g} \mathrm{CoCl}_{0}$ and $5 \mathrm{~kg} \mathrm{FeCl}_{2}$ per day.

Based on the method developed by USU-Metawater Co. Ltd., this research aims to study the effect of reducing concentration of trace metal used in the processing of POME especially nickel and cobalt to biogas production produced from the process of POME at the anaerobic thermophilic condition. This is important to know the minimum values of nickel and cobalt concentration in the digester since these two metals are poisonous metals for the living thing if exist in high concentration.

\section{MATERIALS AND METHOD}

In this research, POME was used as raw material collected from a sludge oil recovery system of factory's wastewater installation belongs to a palm oil company in North Sumatra. Thermophilic bacteria was obtained from wastewater treatment installation of dairy milk factory belong to Metawater Co.Ltd-Japan. Hydrochloric acid solution, sodium bicarbonate, the metallic solution of trace metals; iron (II) chloride, nickel (II) chloride hexahydrate $\left(\mathrm{NiCl} .6 \mathrm{H}_{2} \mathrm{O}\right)$ and cobalt (II) chloride hexahydrate $\left(\mathrm{CoCl}_{2} \cdot 6 \mathrm{H}_{2} \mathrm{O}\right)$ were used as supporting material. The addition of $\mathrm{NaHCO}_{3}$ is used to maintain the $\mathrm{pH}$ and the content of M-Alkalinity. The addition of $\mathrm{FeCl}_{2}$ is used to reduce $\mathrm{H}_{2} \mathrm{~S}$ production, while $\mathrm{NiCl} .6 \mathrm{H}_{2} \mathrm{O}$ and $\mathrm{CoCl}_{2} \cdot 6 \mathrm{H}_{2} \mathrm{O}$ are needed for anaerobic metabolism.

The fermentation process occurred in a 2-litre-capacity digester (EYELA, MBF 300ME) and operated at temperature of $55 \pm 0.5^{\circ} \mathrm{C}$. The digester was provided with double walled water jacket to control the temperature, a data logger (KEYENCE, Model NR-250) to enable recording the temperature and $\mathrm{pH}^{5}$. The $\mathrm{pH}$ was maintained in the range of 6.5-7.86. M-alkalinity was maintained $\geq 3,000$ $\mathrm{mg} / \mathrm{L}$ with the addition $2.5 \mathrm{~g}$ of $\mathrm{NaHCO}_{3} / \mathrm{L} \mathrm{POME}^{7}$. Concentrations of trace metal were varied after the HRT 6 days reached. The parameters noted during the experiment were biogas generation, TS, VS, and M-alkalinity. Biogas generation was measured by using a wet gas meter (Shinagawa, Model W-NK-0.5B), while other parameters were measured as shown in Table 1.

Table 1: Analytical methods for measuring concentration of biogas ${ }^{8}$

\begin{tabular}{lll}
\hline Parameters & Unit & Methods \\
\hline M-Alkalinity & $\mathrm{mg} / \mathrm{L}$ & APHA 2320B \\
Total Solid (TS) & $\mathrm{mg} / \mathrm{L}$ & APHA 2540B \\
Volatile Solid (VS) & $\mathrm{mg} / \mathrm{L}$ & APHA 2540E \\
\hline
\end{tabular}

\section{RESULTS AND DISCUSSIONS}

\section{Biogas Generation}

The addition of nickel and cobalt at the loading up process were 0.49 and $0.42 \mathrm{mg} / \mathrm{L}$, respectively. After HRT 6 days were reached, the addition of nickel and cobalt was reduced. Two concentration variations were used in this experiment, $0.042 \mathrm{mg} / \mathrm{L}$ cobalt and $0.049 \mathrm{mg} / \mathrm{L}$ nickel in $\mathrm{F} 1$ and $0.007 \mathrm{mg} / \mathrm{L}$ cobalt and $0.007 \mathrm{mg} / \mathrm{L}$ nickel 
in F2. Fig. 1 shows gas generation in F1 and F2. In F1, HRT 6 days was reached on the 16th day and 18th day for digester 2. Both graphs for F1 and F2 show that the gas productions fluctuate and show the same trend.

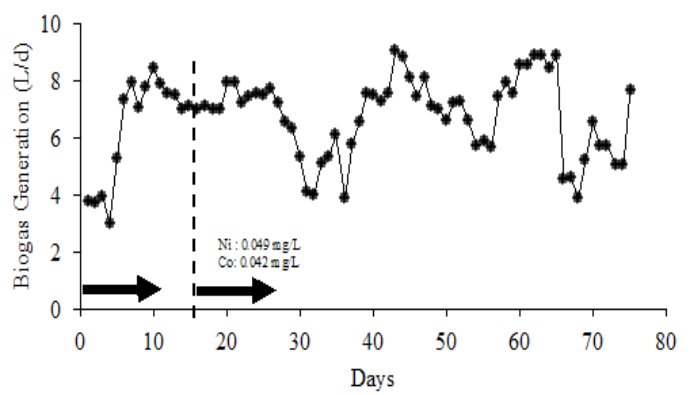

(a). Digester 1 (F1)

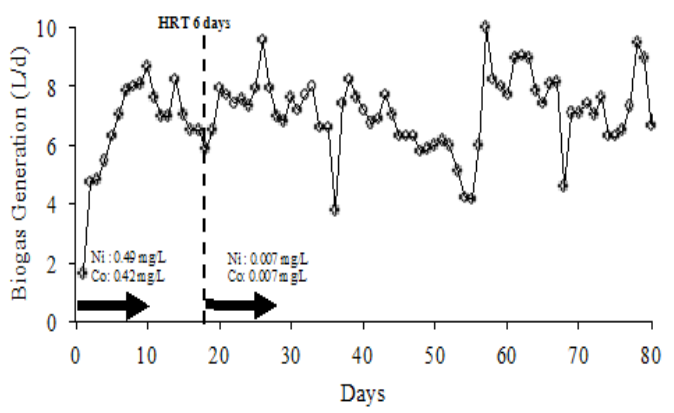

(b). Digester 2 (F2)

Fig. 1. Biogas generation in F1 (a) and F2 (b)

After the reduction of nickel and cobalt, biogas production in F1 ranged from 3.84 to 9.04 L/day and began to increase on day 6 which reached 7.30 L/day and on day 10 reached $8.45 \mathrm{~L} /$ day. Although a slight decrease occurred on the next day, the volume of biogas remained above 7 L/day. This indicates that microorganisms began to adapt and was gradually lowered from HRT 20 days to 6 days which achieved in 18 days. Starting on the 19th day the use of nickel and cobalt as trace metal were reduced to $90 \%$ of the initial concentration, $0.049 \mathrm{mg} / \mathrm{L}$ for nickel and $0.042 \mathrm{mg} / \mathrm{L}$ for cobalt. The volume of biogas obtained was $7.10 \mathrm{~L} /$ day in average. Although fluctuations occurred biogas production tends to be high.

Biogas productions often decreased many times, but the volume was still relatively high because the need for trace metal is always available, even though it was small enough to meet the needs for microorganisms in both digester. High methane production may be related to concentration of trace metals and methanogen population which still exist in the anaerobic process. The adequate concentration of trace metal can affect the activity of methanogen microorganisms ${ }^{9}$.

In digester 2 (F2), biogas production ranged from 4.86 to $10.5 \mathrm{~L} /$ day. The volume of biogas obtained fluctuated where it began to increase at day 6 reaching $7.07 \mathrm{~L} /$ day, indicating that microorganisms have adapted. On the 19th day, the use of trace metals was reduced to $0.007 \mathrm{mg} / \mathrm{L}$ for nickel and $0.007 \mathrm{mg} / \mathrm{L}$ for cobalt. Until the 24th day, production of biogas was above $7 \mathrm{~L} /$ day. The volume of biogas reached its highest point on day 57 which reached $10.5 \mathrm{~L} /$ day, but the average biogas production after the reduction of nickel and cobalt was about 6.68 L/day. This is in accordance with study conducted by Raju et al. where they obtained biogas of $0.49 \mathrm{~m} 3 / \mathrm{kg}$ VS from a reactor using trace metals and only 0.22 $\mathrm{m} 3 / \mathrm{kg}$ VS from a reactor without trace metals ${ }^{10}$.

Methanogen activity is influenced by the presence of coenzymes and cofactors that support the metabolism process. Coronoid and cofactors F430 are coenzymes and cofactors which can increase methanogen metabolism, where the coronoid and F430 assist in the reaction of methyl displacement and form an intermediate compound which then reacts with $\mathrm{HS}-\mathrm{CoM}$ and methyl-CoM ${ }^{11}$. Therefore, the presence of nickel and cobalt in the anaerobic reaction may affect the activity of methanogen bacteria in producing methane. The concentration difference of nickel and cobalt in the two digesters have little effect on biogas production, it means that trace metal reduction up to $97 \%$ of the initial concentration can still produce optimum biogas although the average volume is slightly lower.

Effect of Trace Metal Concentration, Reduction on Total Solid and Volatile Solids

Total solid (TS) is the amount of inorganic and organic solids contained in the waste, while volatile solid (VS) is the amount of organic material converted into biogas in waste. Fig. 2 shows the amount of TS and VS of digested slurry in F1 and F2.

Figure 2 shows that in both digesters the TS concentration is relatively low from day 9 to day 28. This indicates that the adaptation of microorganisms present in the digesters works well 
enough to decrease TS. However, after the 26th day, the TS value of both digesters starts to increase until $23.769 \mathrm{mg} / \mathrm{L}$ in $\mathrm{F} 1$ and $22.685 \mathrm{mg} / \mathrm{L}$ in $\mathrm{F} 2$. This happens because the concentrations of trace metals contained in the digesters are so small that the fermentation process is not running optimally. High TS values indicate that the performance of microorganisms is less optimal so that the biogas produced will also decrease. The amount of biogas produced is a function of the concentration of TS in the digester ${ }^{12}$.

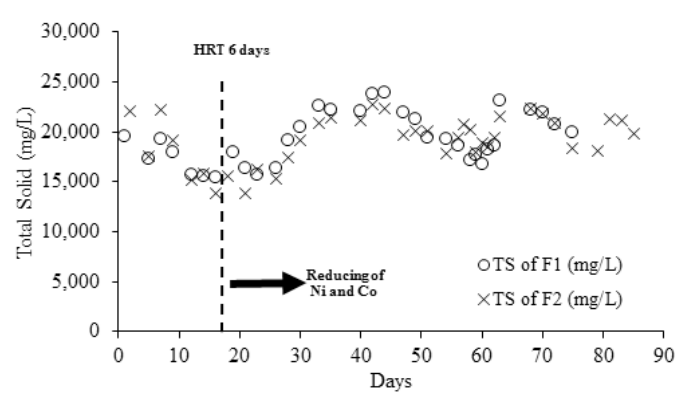

(a). TS concentration in F1 and F2

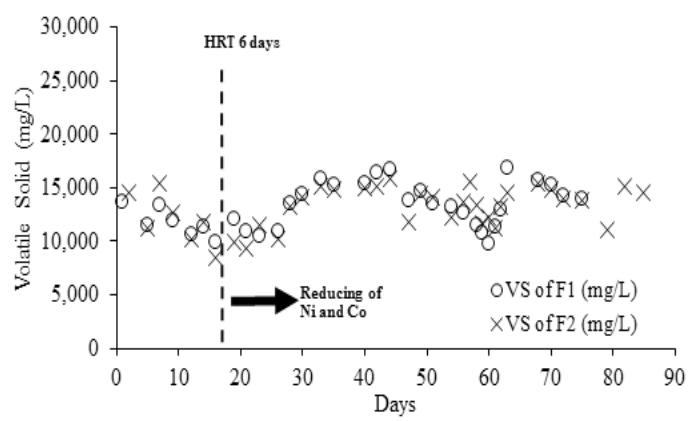

(b). VS concentration in F1 and F2

Fig. 2. The amount of TS (a) and VS (b) of digested slurry in F1 and

The amounts of VS in both digesters were quite low from day 9 to day 28 , but the value increased to $16.707 \mathrm{mg} / \mathrm{L}$ in $\mathrm{F} 1$ and $15.894 \mathrm{mg} / \mathrm{L}$ in F2. VS values that are still high in both digesters after the 26th day indicated that less optimal biodegradation of organic compounds in the digester to form biogas. One of the causes of this occurrence is the lack of nickel and cobalt as micronutrients needed by methanogenic bacteria. However, the volume of biogas produced was quite satisfactory. There is a similar trend as shown in Fig. 2, where the amount of VS in the digester decreased then biogas production increased and vice versa. Hence it can be seen that the decrease in the values of TS and VS indicate that many organic compounds are degraded and form biogas so that the production of biogas increases.

\section{Effect of Trace Metals Concentration}

\section{Reduction on M-Alkalinity}

In anaerobic fermentation, alkalinity levels should range between $2,000 \mathrm{mg} / \mathrm{L}$ to $5,000 \mathrm{mg} / \mathrm{L}$. This range is intended to neutralize volatile acids and also to maintain the $\mathrm{pH}$ change. Fig. 3 shows the M-alkalinity of digested slurry in F1 and F2.

From Fig. 3, the range of M-alkalinity in $\mathrm{F} 1$ is $2,700 \mathrm{mg} / \mathrm{L}$ to $4,500 \mathrm{mg} / \mathrm{L}$ and M-alkalinity in $\mathrm{F} 2$ ranged from $2,400 \mathrm{mg} / \mathrm{L}$ to $4,400 \mathrm{mg} / \mathrm{L}$. $\mathrm{M}$-alkalinity values in these two digesters are still in the recommended range for anaerobic fermentation reaction. Thus the reaction can still work properly because of the condition of alkalinity in the digesters are still supporting the growth of anaerobic microorganisms. Reduction of trace metal concentrations has no effect on the alkalinity in the digesters.

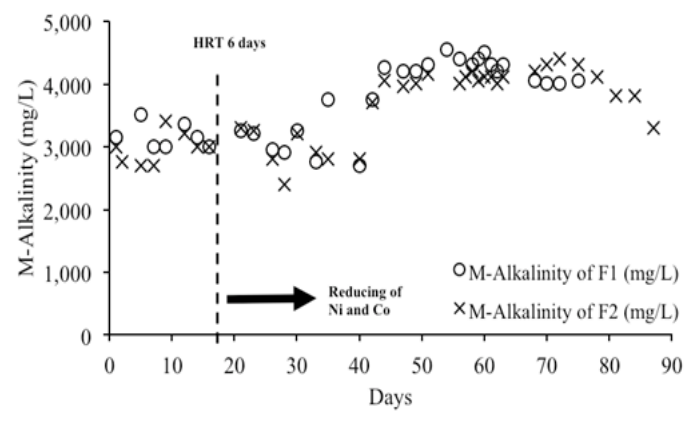

Fig. 3. M-alkalinity in F1 and F2

Effect of Trace Metal to volatile solid degradation

Reduction of nickel and cobalt concentrations in F1 and F2 affects VS degradation in the digesters. The percentage of VS degradation in the digester is shown in Figure 4.

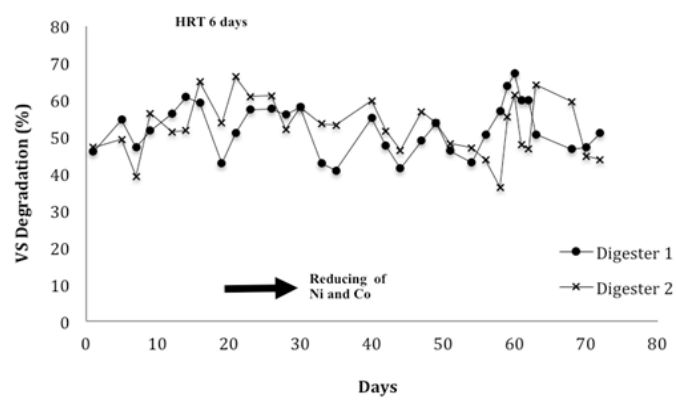

Fig. 4. VS degradation in the digester 
The degradation of VS in both digesters have slightly different trends, but the average of VS degradation in both digesters is above $40 \%$, although in F2 at certain days the percentage of the VS degradation is less than $40 \%$. In F1, it is seen that the decomposition of VS is between $40-67 \%$. Fluctuation of VS degradation might be affected by the feeding of fresh POME pumped into the digester every day then the activity of microorganisms decreased slightly. In F2, the values of VS degradation range from 36 to $66 \%$, smaller than in $\mathrm{F} 1$ but the difference of VS degradation of both digesters is not too significant. From the two digesters, it can be obtained the average VS degradations are 53\% for $\mathrm{F} 1$ and $52 \%$ in F2. VS degradation in F2 is slightly lower than F1 because the concentration of trace metal used is also smaller. Trace metal can affect the degradation of VS in anaerobic systems ${ }^{13}$. If the decomposition of acetate or propionate by methanogens is in trouble then volatile fatty acid will accumulate, then it can interfere the next step in fermentation process ${ }^{14}$.

\section{CONCLUSION}

This study has demonstrated the minimum requirements of nickel and cobalt as trace metals in thermophilic biogas fermentation of POME. Results indicated that reduction of trace metal concentrations didn't have effect on levels of TS and VS, alkalinity for both digesters, and still at the recommended range for growth of microorganisms. In addition, the reduction up to $97 \%$ of the initial concentration still allowed the fermentation to obtain optimum biogas production. Biogas generation can be reached 10.5 L/day when trace metals was reduced to $0.007 \mathrm{mg} / \mathrm{L}$ for nickel and $0.007 \mathrm{mg} / \mathrm{L}$ for cobalt, that considered as the minimum requirements for trace metals in this study.

\section{ACKNOWLEDGMENT}

This research was supported by Hibah Penelitian Unggulan Perguruan Tinggi fiscal year 2015 No: 118/UN5.2.3.1/PPM/SP/2015 date 2 March 2015 and Metawater Co., Ltd-Japan.

\section{REFERENCES}

1. Bala, J.D.; Lalung, J.; Ismail, N.; Int. J. Sci. Res. Pub., 2014, 4, 502-511.

2. Adekunle, K.F.; Okolie, J.A.; Adv. in Biosci. Biotech., 2015, 6, 205-212.

3. Manyi-Loh, C.E.; Mamphweli, S.N.; Meyer, E.L.; Okoh, A.I.; Makaka, G.; Simon, M.; Int. J. Environ. Res. Public Health., 2013, 10, 43904417.

4. Irvan; Trisakti, B.; Sosanty, F.; Tomiuchi, Y.; Asian J. Chem., 2016, 28, 377-380.

5. Irvan; Trisakti, B.; Maulina, S.; Daimon, S.; Rasayan J. Chem., 2018, 11(1). 378-385.

6. Wun, W.L.; Chua, G.K.; Chin, S.Y.; J. Clean WAS., 2017, 1(2). 6-9.

7. Irvan; Trisakti, B.; Maulina, S.; Daimon, S.; Orient. J. Chem., 2018, 34(1), 161-168.

8. APHA, Standard methods for the examination of water and wastewater, 20th ed. Washington
(DC, USA): American Public Health Association, 1998.

9. Wong, Y.S.; Teng, T.T.;Ong, S.A.; Norhashimah, M., Rafatullah, M.; Lee, H.C.; Procedia Environ. Sci., 2013, 18, 433-441.

10. Raju, N.R.; Sumithra, D.S.; Nand, K; Biotechnol. Lett. 1991, 13(6), 461-464.

11. Sonakya, V.; Raizada, N.; Kalia, V.C; Biotechnol. Lett., 2001, 23, 1463-1466.

12. Hullebusch, E.D.; Guibaud, G.; Simon, S.; Lenz, M.; Yekta, S.S.; Fermoso, F.G.; J. Crit. Rev. Env. Sci. Tech., 2016, 46(16) 13241366.

13. Igoni, A.H.; Abowei, M.F.N.; Ayotamuno, M.J.; Eze, C.L.; Agricultural Eng. Int: the CIGR Ejournal., 2008, X, 07-010.

14. Schmidt, T.; Waste Manag. Res., 2011, 29(11) , 1171-6. 